\title{
Ethnographic Films from Prisoner-of-War Camps and the Aesthetics of Early Cinema
}

\author{
Wolfgang Fuhrmann
}

In the summer of 1915, the Austrian Ministry of War gave permission for a group of Austrian anthropologists to perform fieldwork in prisoner-of-war (POW) camps located in Eger, Reichenberg, and Theresienstadt. ${ }^{1}$ The programme had been initiated by the Viennese Anthropological Society several weeks earlier at its June meeting, after its president argued that scientists should not miss the chance to examine soldiers from all over Europe. The camps gathered ethnic groups normally scattered across vast regions, ${ }^{2}$ providing research opportunities unlikely to be repeated in the foreseeable future. ${ }^{3}$ Under the direction of Rudolf Pöch, a central figure in Austrian anthropology and ethnography at the time, anthropologists began work in the POW camp in Eger in July 1915. The group collected personal and anthropometric data, took photographs, and recorded songs and stories with a phonograph. In addition, Pöch soon began shooting films of the prisoners as they demonstrated traditional customs and craft-making.

Using a movie camera in anthropological fieldwork was neither a novelty in the discipline, nor was it a new technology for Pöch. Ethnographic film had been established in German-speaking anthropology for nearly ten years. Films like Völkerkundliche Aufnahmen aus der Südsee aus den Jahren 1908-1910

1 Rudolf Pöch, "1. Bericht über die von der Wiener Anthropologischen Gesellschaft in den k.u.k. Kriegsgefangenenlagern veranlaßten Studien," Mitteilungen der Anthropologischen Gesellschaft in Wien 45 (1915): 219-235.

2 The Society's President Carl Toldt quoted in Andrea Gschwendtner, "Als Anthropologe im Kriegsgefangenlager-Rudolf Pöchs Filmaufnahmen im Jahre 1915," Wissenschaftlicher Film 42 (1991): 107.

3 Pöch, "1. Bericht," 219. 
[Ethnological Film Documents from the Pacific in the Years 1908-1910] from the Hamburg South Seas Expedition or Aus dem Leben der Kate auf Deutsch Neuguinea: Aufnahmen aus dem Jahre 1909 [From the Life of the Kate in German New Guinea-Pictures from the Year 1909] by Richard Neuhauss document the discipline's interest in the new medium. ${ }^{4}$ Pöch himself had been among the first ethnographers to exploit film. He purchased a movie camera during his New Guinea expedition of 1904-1906, having realized that photographs were inadequate to record dance choreographies. ${ }^{5}$ During his next expedition, 1907-1909, Pöch filmed in the Kalahari. ${ }^{6}$ His film Bushman Speaks into a Phonograph has become one of the most cited early documents in ethnographic film history.

Pöch's POW-camp films leave today's viewers uneasy. In principle, they were part of an anthropological research project and, thus, no more or less problematic than many other ethnological films of the time. But the POW camp setting itself conveys a strange blend of scientific interest, humiliation, and voyeurism. Visibly staged performances appear to contravene Pöch's statements regarding the objectivity of the cinematographic apparatus and the authenticity of the events he filmed.

This chapter approaches Pöch's POW-camp film recordings from the perspective of film history. Focusing on the aesthetics of early nonfiction films on colonial themes, the chapter seeks to situate Pöch's wartime films, which were not the first of their kind, in a broader filmmaking context. General audiences had seen similar films, made ten years before Pöch arrived in Eger, shot in the concentration camps set up by the colonial government of German Southwest Africa during the Herero and Nama War (1904-1907). Furthermore, film was just one element in a whole industry of representing colonial subjects that extended from picture postcards to popular illustrated journals. All of these media employed an aesthetic quality and sequential logic that aimed at making even a concentration camp seem picturesque and exciting. ${ }^{7}$

The intention here is not to argue that Pöch's scientific films are indistinguishable from, or equivalent to, commercial film for popular entertainment. But viewing Pöch's short-lived POW-camp film project in the context of early film aesthetics can help make them more legible to us today. Conventions of

4 The unique collection of early German ethnographic films including Rudolf Pöch's films are archived at the IWF Wissen und Medien gGmbh in Göttingen, Germany. http://www.iwf.de/IWF (accessed February 9, 2010).

5 Rudolf Pöch, "Reisen in Neu-Guinea in den Jahren 1904-1906," Zeitschrift für Ethnologie 39 (1907): 382-400.

6 "Photographie und Kinematographie bei den Buschmännern," Photographische Korrespondenz 581 (1909): 94.

7 Tom Gunning, "The Cinema of Attractions: Early Film, its Spectator and the Avant-Garde," in Early Film: Space-Frame-Narrative, eds. Thomas Elsaesser and Adam Barker (London: British Film Institute, 1990), 56-62. 
representation dominant in early cinema exercised considerable pressure even on anthropological filmmaking. The abrupt end of Pöch's endeavors may also comment on film's contested role as an ethnographic tool in the scientific community.

\section{Representations of the POW Camp: German Southwest Africa, 1904-1909}

When the Herero and Nama War broke out in January 1904, the distance between the European metropole and the African colony did not allow for immediate media coverage. However, the war became one of the first proving grounds for modern mass media in Germany, with panoramas, picture postcards, photography, and film contributing to visual representation of the war at home. As early as February 1904, painted panoramas two square meters in size were advertised as "fast and cheap" in a trade journal for fairground operators, Der Komet. ${ }^{8}$ They sold well, so that fairs and amusement parks provided some of the earliest opportunities for the German public to view images of the military campaign in the colony.

That December, Chancellor Bülow ordered the establishment of "concentration camps" for the "temporary accommodation and lodging of the remainder of the Herero people." In the following months, numerous official and semiprivate camps were set up throughout the colony, confining Africans under inhuman conditions. Access was not restricted to military or government officials, but was open to both amateur and professional photographers and cameramen. It was only a matter of time until a new genre of war representations entered the public market-photographs of captive Herero and Nama.

One amateur who exploited the chance to shoot photographs and films in the camps was the Altenburg merchant and brewery owner Julius Friedrich Carl Müller (1868-1935). To promote his business at home and obtain material for colonial propaganda, Müller visited the German colonies twice, first in 1904-1905 and again in 1906. Screenings of his films at local chapters of the Deutsche Kolonialgesellschaft [German Colonial Society] made him a wellknown figure in the colonial movement. ${ }^{10}$ Staying in close contact with his

8 Der Komet, no. 986, February 13, 1904, 32.

9 Joachim Zeller, "'Ombepera i koza-Die Kälte tötet mich': Zur Geschichte des Konzentrationslagers in Swakopmund 1904-1908," in Völkermord in Deutsch Südwestafrika, eds. Jürgen Zimmerer and Joachim Zeller (Berlin: Ch. Links Verlag, 2003), 64-85, quotes from p. 65.

10 Wolfgang Fuhrmann, "Bilder aus den deutschen Kolonien: Lichtbilder und kinematographische Aufnahmen," in KINtop. Jahrbuch zur Erforschung des frühen Films 8 (1999): 101-116. 


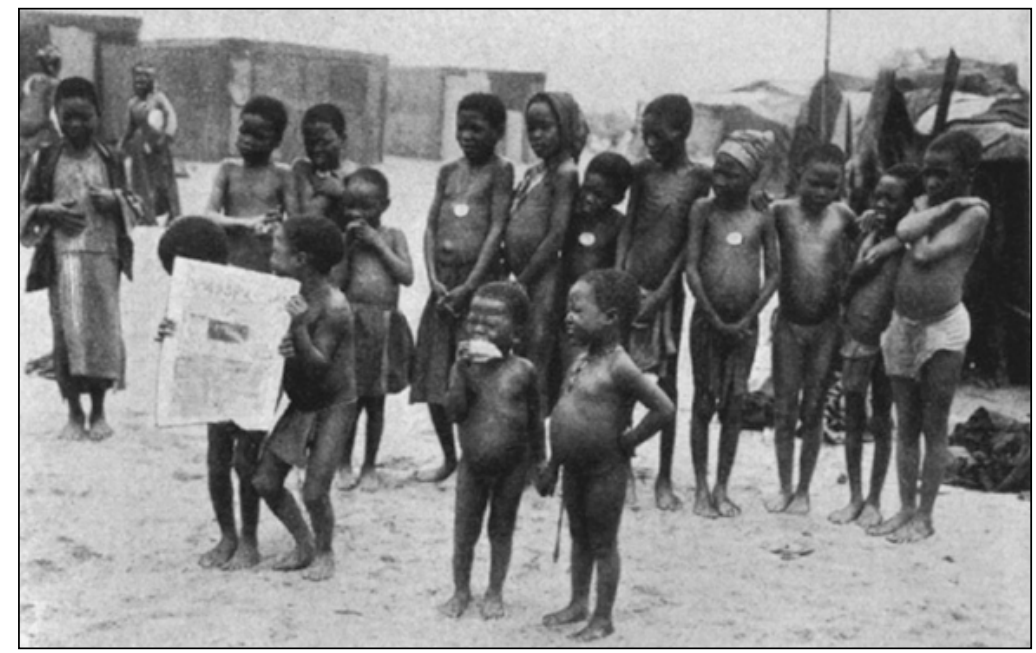

Figure 1. Herero children in a camp in German Southwest Africa, 1906. Photograph by Julius Friedrich Carl Müller. Source: Ottomar Bettziech, Das Buch von unsern Kolonien, 4th rev. ed. (Leipzig: Ferdinand Hirt \& Sohn, 1908), 59.

family and his hometown, Müller regularly sent notes and photographs. One camp scene showed sixteen African children wearing tags that identify them as prisoners. The photograph was first displayed in the window of a bookshop in Altenburg. Commentary in local newspapers over the next few days emphasized the picture's "entertaining character" (Figure 1).

The photograph shows [...] 16 Negro babies of varying size, of whom two little boys have concealed themselves behind an issue of the Altenburg newspaper to read it. The photograph of the little black compatriots is technically impeccable. The card will surely brighten many people's day. ${ }^{11}$

The photograph is a striking example of colonialism's reception and exploitation in imperial Germany. The image stood in sharp contrast to reality. The missionary Heinrich Vedder remarked that the Roheit, geile Sinnlichkeit, and Herrentum [brutality, lecherous sensuality, and arrogance] that had spread among troops and civilians was such that it would be impossible to exaggerate the horror of the camps. ${ }^{12}$ None of that is evident in the light-hearted caption ("little black compatriots") attached to the visibly malnourished children and toddlers.

11 "Altenburger Zeitung für Stadt und Land, April 10, 1906.

12 For a discussion of the photographs from POW camps during the Herero War, see Joachim Zeller, "Wie Vieh wurden hunderte zu Tode getrieben und wie Vieh begraben': Fotodokumente aus dem deutschen Konzentrationslager in 


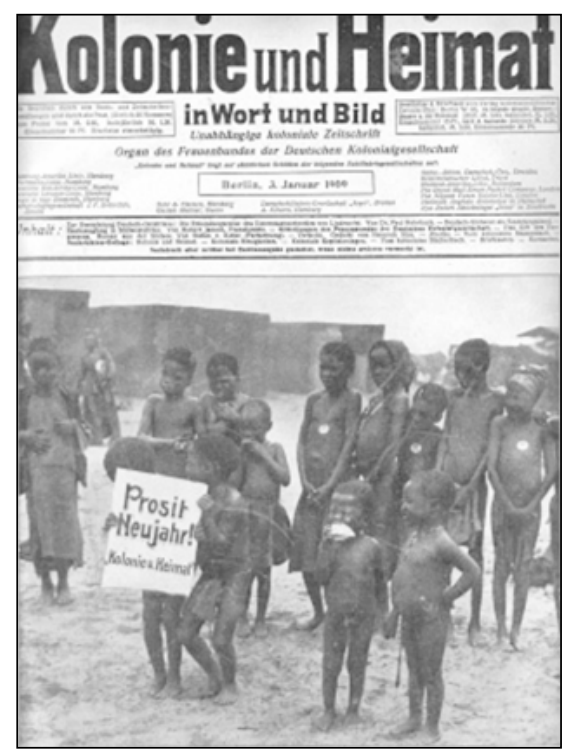

Figure 2. "Idyll in a Herero Village (werft)." Photograph taken in a concentration camp by Müller. Source: Kolonie und Heimat, January 3, 1909, 1 .

In the following weeks and months, the image circulated in Germany as a picture postcard. More than a consumer product to be purchased, sent, sold, and traded, it became a media palimpsest. Whether as window dressing, postcard, or illustration, the image produced new meanings again and again. One example is its reprinting in a popular colonial journal in 1909 (Figure 2).

The image is the same as that displayed in the Altenburg shop window three years earlier, but cropped and retouched. In the context of a concentration camp, the children holding a sign that reads "Cheers! Happy New Year!" might appear rather cynical, but the new caption "Idyll in a Herero Village" suggests that the picture was taken in front of typical Herero dwellings outside a colonial city. It is unclear whether readers were aware of the photograph's actual origin and were amused by the caption or whether they sincerely believed the caption that transformed the memory of a murderous war into a happy idyll. Whatever contemporaries would have answered, pictures of Herero and Nama prisoners formed part of a racist media practice with new distribution and exhibition contexts producing their own colonial reality. Film was also a part of this practice.

No comprehensive tally of films shot in the camps exists. However, films, such as Bilder aus dem Kriegs- und Friedensleben [Images of War- and Peacetime] from Robert Schumann, 1907; Land und Leute in Deutsch-Südwest-Afrika [Land and People in German Southwest Africa], from Deutsche Mutoskope und Biograph, 1907; Südwest-Afrika from Deutsche Bioscope, 1907; and the films made by Müller were among those depicting the war and its aftermath. ${ }^{13}$

Swakopmund/Namibia 1904-1908," Zeitschrift für Geschichtswissenschaft 3 (2001): 226-243.

13 At least in one case we know about a film that was shot in a prison camp in German East Africa. The Pathé catalogue lists the film "Un bagne en Afrique orientale allemande" [A penitentiary in German East Africa], April 1910. According to a brief summary, the film showed "the rude and miserable life 
To understand the films in a film-historical context requires more than just labeling them "colonialist"-which is tantamount to formulating a tautology, as media historian Klaus Kreimeier remarks. ${ }^{14}$ More productive is to address how film in colonial times organized "views" and visual regimes.

\section{The Colonial Travelogue Film in Wartime}

Examination of surviving films as well as the titles, reviews, advertisements, and summaries of films that have been lost reveals that the form considered most appropriate for representing the colonies to the national film audience was the travelogue. Generally composed of a montage of emblematic scenes, travelogues were one of the most popular genres in early cinema for illustrating foreign places or regions. As Jennifer Peterson remarks, they served "as vicarious travel, as a substitute for actual travel that could be experienced by those without the financial means to tour around the globe."15

The travelogue relies on the aesthetic of the "view," which film historian Tom Gunning calls the Urform of early documentary film. ${ }^{16}$ The term highlights "the way early actuality films were structured around presenting something visually, capturing and preserving a look or a vantage point." ${ }^{17}$ The "view" is a constituent element in a "cinema of attractions" that focused on showing, rather than telling, stories and was the dominant form before $1906{ }^{18}$ The cinema of attractions "directly solicits spectator attention, inciting visual curiosity, and surprisingly pleasure through an exciting spectacle-a unique

of a prisoner in Africa: putting chains on the prisoners' neck, visit of the director, the labor duties (les corveés) with wood, water, and stones, the meals, and the punishments." Even though we cannot rule out that the film was shown in Germany, no evidence exists in the German trade journals that the film was officially distributed or sold in Germany. Henri Bousquet, ed., Catalogue Pathé des Années 1896 á 1914, 1910-1911 (Buressur-Yvette: Bousquet, 1994), 282.

14 Klaus Kreimeier, "Mechanische Waffen und Haudegen überall: Expeditionsfilme; Das bewaffnete Auge des Ethnografen," in Triviale Tropen: Exotische Reise- und Abenteuerfilme aus Deutschland 1919-1939, ed. Jörg Schöning (Munich: edition text + kritik, 1997), 47.

15 Jennifer Peterson, "'Truth is Stranger than Fiction': Travelogues from the 1910s in the Nederlands Filmmuseum," in Uncharted Territory: Essays on Nonfiction Film, eds. Daan Hertogs and Nico de Klerk (Stichting: Nederlands Filmmuseum, 1997), 78.

16 Tom Gunning, "Before Documentary: Early Nonfiction Films and the 'View' Aesthetic," in Hertogs and de Klerk, Uncharted Territory, 14.

17 Ibid.

18 Gunning, "The Cinema of Attractions," 56. 
event, whether fictional or documentary, that is of interest in itself." ${ }^{19}$ However, in contrast to an attraction, like a filmed comedic gag or vaudeville act, Gunning considers the view as possessing a "greater claim to recording an event of natural or social history." ${ }^{20}$

"Views" tend to carry the claim that the subject filmed either pre-existed the act of filming (a landscape, a social custom, a method of work) or would have taken place even if the camera had not been there (a sporting event, a funeral, a coronation), thus claiming to capture a view of something that maintains a large degree of independence from the act of filming it. ${ }^{21}$

In film, the view does not simply unfold a landscape in front of the viewers' eyes, but emulates the act of looking, so that the camera "literally acts as tourist, spectator or investigator." 22 The audience's pleasure in the "view-film" thus lay in the "surrogate of looking." 23

The "views" of the travelogue explore what Peterson calls a "central obsession of Western visual culture from the nineteenth century through the First World War: images of the other and of other places and images of the changing modern world." ${ }^{4}$ As viewers explored the exotic world of the Other, the conventions of the travelogue genre demanded "fascinating yet potentially threatening moving images." 25 In other words, while the travelogue's formulaic structure presented a wide range of exotic views, its explorations were secured by "the familiar confines of the travelogue genre."26

It is this tension between the "different" and the "normal" that fuels the travelogue. It is a delicately-balanced polarity: crudely put, the place presented must merit the curious filmgoers' gaze, therefore the place must be (constructed as) exotic, yet in this presentation there is at the same time a certain disavowal of that exoticism, a desire to mark what is Other and then contain it, to keep it at arm's length. ${ }^{27}$

This tension has been highly efficacious and adaptable, as Peterson points out, characterizing the colonial and exotic landscapes of film as European locales. ${ }^{28}$ Travelogues refer to places that exist in the real world, but, as representations,

19 Ibid.

20 Gunning, "Before Documentary," 14.

21 Ibid.

22 Ibid., 15.

23 Ibid.

24 Peterson, "Truth is Stranger than Fiction," 76.

25 Ibid.

26 Ibid.

27 Ibid., 81.

28 Ibid., 76. 
they present an entirely new "idealised cinematographic geography" that exists geographically only on the screen. ${ }^{29}$

When analyzing representations of colonies, the travelogue's ambivalence - its confining the exotic to a strict set of conventions-must be further differentiated. While colonial travelogues certainly addressed their audiences through exotic locations and visual novelties, it was not merely genre convention that defined the experience of the exotic Other. Colonial travelogues explicitly tried to subdue the exotic by emphasizing colonies' most familiar aspects; colonial ideology did not want to unnerve people, but to attract them. The "view" aesthetic in colonial travelogues thus has an important secondary connotation. John Noyes points out that the appropriation of space is a key issue in German colonial discourse, closely related to the way of looking: "When the colonizer arrives in a new territory, the gaze with which he surveys it is an initial appropriation of space. It defines spaces of objectivity and establishes relations between these spaces." 30 The organization of colonial space into structures was therefore "conducive to the functioning of the colony." ${ }^{11}$ To watch colonial films with the colonial "view" means, for instance, to be aware of the particular power relation between scenes of colonizers and colonized or of how the sequential logic of a travelogue was organized.

One of the first travelogues from the German colonies to reach German cinemas was Südwest-Afrika in 1907. The film has not survived, but, since early films were not rented but sold, a production company handbill provides information about the film's content. The film was made in 1907 by a German, Georg Furkel, for Deutsche Bioscope. ${ }^{32}$ Other clients included a railroad construction company, Lenz \& Co., that ran its own work camps, impressing Africans into forced labor. ${ }^{33}$ The various "views" listed in the advertisement (Figure 3) evidence the influence of political events: While the shot order in travelogues often appears scattered and loose, a closer look at Südwest-Afrika shows that the composition of the individual shots seems to follow a visual dramaturgy in which recent events in German Southwest Africa are integrated

29 Jennifer Peterson, "World Pictures: Travelogue Films and the Lure of the Exotic 1890-1920" (PhD thesis, University of Chicago, 1999), 32. John Noyes, Colonial Space: Spatiality in the Discourse of German South West Africa 1884-1915 (Chur: Harwood Academic Publishers, 1992), 163.

31 Ibid., 18.

32 Parallel to this, the Deutsche Mutoskope- und Biograph $\mathrm{GmbH}$ released "Leute in Südwest Afrika" [People in Southwest Africa] with "original scenes from the theatre of war [Kriegsschauplätze]," Der Komet, no. 1162, June 20, 1907,2 . No information about the content of this film could be found.

33 Georg Furkel, "Film vor 30 Jahren," Der Kinematograph, November 7, 1926, 15-16; ibid., November 14, 1926, 11-12; ibid., November 21, 1927, 11-12. 


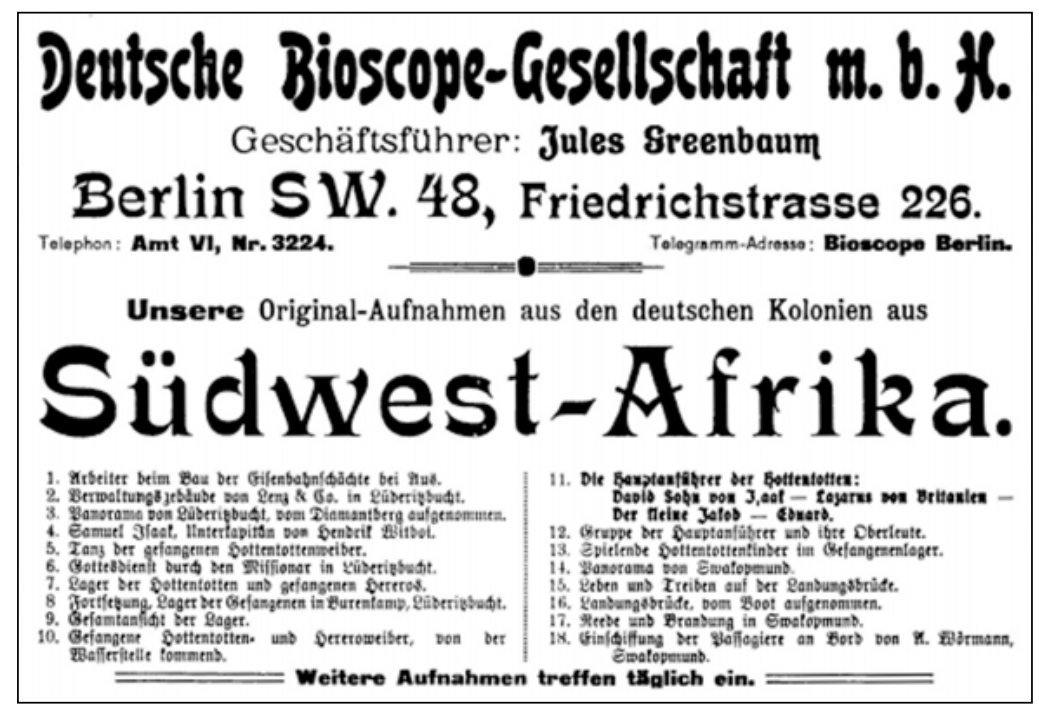

Figure 3. Advertisement for the Deutsche Bioscope film Südwest-Afrika by Georg Furkel, 1907. Source: Der Komet, no. 1158, June 1, 1907, 16.

into processes of colonization and progress. ${ }^{34} \mathrm{~A}$ violent past is softened by the film's sequential logic.

The film starts with shots of workers, company property, and the bay:

(1) Workers at the construction sites of railway shafts near Aus.

(2) Administration buildings of Lenz \& Co. in Lüderitzbucht.

(3) Panorama of Lüderitzbucht from Diamond Mountain.

The next nine scenes are dedicated to the Herero and Nama ("Hottentot") prisoners:

(4) Samuel Isaak, subcaptain of Hendrik Witboi.

(5) Dance of imprisoned Hottentot women.

(6) Religious service by the missionary in Lüderitzbucht.

(7) Camp of the Hottentot and imprisoned Herero.

(8) Continuation, POW camp in Burenkamp, Lüderitzbucht.

(9) Overall view of the camp.

(10) Captive Hottentot and Herero women returning from fetching water.

(11) The main leaders of the Hottentot: David, son of Isaak-Lazarus of Britain -The small Jakob-Eduard.

(12) Group of the main leaders and their subordinates.

(13) Hottentot children playing in the POW camp.

34 Peterson, "World Pictures," 126. 
In this second series of scenes, number eleven, printed in boldface, was apparently intended to be the film's highlight: the leaders of the Nama warriors. After this climax, the next seven shots show Nama children playing in the concentration camp, a panorama of Swakopmund, life on the jetty, roads and shore, and, finally, passengers boarding a steamer:

(14) Panorama of Swakopmund.

(15) Hustle and bustle on the jetty.

(16) Jetty, taken from a boat.

(17) Harbor and surf in Swakopmund.

(18) Passengers boarding the A. Wörmann, Swakopmund.

The three groups of shots-Lüderitzbucht, POW camp, Swakopmund-establish rather different spaces in the same locality.

The high point of Südwest-Afrika is plainly meant to be the depiction of the rebel leaders in scene eleven, while its contextual integration reassures viewers that the colony is a safe place to live and travel. ${ }^{35}$ In contrast to the POW camp, the opening and concluding scenes, panoramas of colonial cities and progress, emphasize more picturesque aspects. Framed by the construction of infrastructure and the boarding of an ocean liner, the film touts the colonies as a place worth visiting. Likewise, the opening and closing panoramas bracket reminiscences of the colonial war, so that the most violent period in German colonial history becomes integrated into a discourse of progress and peaceful everyday life. ${ }^{36}$ Südwest-Afrika can be considered an example of colonization's creation of discrete spatial units facilitating control and administration of the geographic territory. With Africans fenced into POW camps, traces of the Other have been effaced from colonial territory which is now ready to be filled with colonizers' presence.

Attention to the sequence shows that the film was carefully composed: The three groups of scenes provide a narrative flashback into the history of German Southwest Africa. The transition to the POW camp reminds viewers that the war has only recently ended. The sequence could be seen as an illustration of Michel de Certeau's conception of the division of space as a panoptic practice, ${ }^{37}$ with its views functioning like a surveillance camera to monitor the prisoners. But the prison sequence is not merely a document of punishment:

35 Der Komet, no. 1158, June 1, 1907, 16.

36 One could also argue that the monitoring look of the camera in the POW camp sequence makes possible the integration into the filmic discourse of peace in the colony.

37 Michel de Certeau, The Practice of Everyday Life, trans. Steven Randall (Berkeley, CA: University of California Press, 1984), 36, quoted in Noyes, Colonial Space, 129. 
It also presents the work of missionaries. The POW camp becomes the place where African warriors come to Christ-a beneficent reformatory. ${ }^{38}$

The transition from the POW camp to more pleasant views, such as the panorama of Swakopmund, is mediated by a depiction of children playing, just as the missionary is introduced by the dancing of scene five. Was the transition from Herero fighters to children intended to denigrate the enemy or merely to show that the Herero no longer threatened German life in the colony? Since the film has been lost, we cannot know for sure whether the montage meant to evoke colonialist arguments of the colonized as children or whether the children reprised the dancing women. The film was not intended as a shocker, as its use of landscapes, women, and children indicates. They lend the film an alternating rhythm of threat and amusement, following genre conventions that Peterson describes as a continuous "acting-out of tensions between attraction and repulsion." ${ }^{39}$ Gunning contends that early films make us uncomfortable, because they make the ambivalent power relation of the "view" aesthetic so explicit: The voyeurism of the tourist, the colonialist, the filmmaker, or the spectator reveals itself in the films without the overvoiced narrator or the exculpatory political rhetoric familiar from later documentaries. ${ }^{40}$ The film shows that images rife with implicit racism, violence, and degradation easily found their place within a discourse of spectacle and tourism.

\section{Rudolf Pöch's POW-Camp Films of 1915}

The aesthetic of early cinema, in the form of the "cinema of attractions" and the "view," guaranteed the long-lasting popularity of the travelogue genre and also left its traces on early anthropological filmmaking. "As an Anthropologist in a POW Camp-Rudolf Pöch's Films of 1915" is an archival compilation of Pöch's original film material, published by the Austrian Federal Institute for Scientific Film and includes all fifteen of his surviving ethnographic films. ${ }^{41}$

38 The same reformatory impulse also characterizes Müller's picture postcard of the Herero children that was first presented in the Altenburg shop window. As a postcard, it circulated with the title "Wissbegierige Hereokinder mit Gefangenenabzeichen" [Inquisitive Herero children with prison-camp tags]. The new title does not hide the location of the POW camp, but implies, at the same time, that the presence in the camp serves colonial educational purposes.

39 Peterson, "Truth is Stranger than Fiction," 76.

40 Gunning, "Before Documentary," 24.

41 Andrea Gschwendtner, Als Anthropologe im Kriegsgefangenenlager-Rudolf Pöchs Filmaufnahmen aus dem Jahre 1915, Film P 2208 des ÖWF, Wien. 
(1) The first film shows a theatrical performance, "Wedding Ceremony." The wedding party stands in the foreground, with a male prisoner playing the bride. In the background, we see other prisoners in a semicircle, watching. At the left are two musicians. Various actors enter the frame, including some playing a dancing bear and his tamer, performing (possibly) traditional wedding dances for the bridal couple.

(2) Pan from right to left over the ceremony's audience.

(3) Wrestling match. Three men take turns, with the third acting as referee.

(4) A Russian dance with musicians in the background.

(5) A second Russian dance with musicians in front of a shack.

(6) A third Russian dance. Two men clap the rhythm for the dancing colleague.

(7) Group dance performed by eight men.

(8) Muslim prayer ritual.

Seven scenes of craft manufacturing follow the outdoor scenes above:

(9) Weaving straw shoes. The scene is composed of two shots illustrating different stages in the manufacturing process.

(10) Making a balalaika.

(11) Whittling bone. From a medium objective, a second shot moves the camera closer to allow viewers to follow the craft in more detail.

(12) Turning a coin into a ring.

(13) Making a wooden pigeon (interior?).

(14) Making a toy snake (interior?).

(15) Making a plaster cast of a prisoner's face. This process is shown in two additional shots.

Not knowing the exact sequence in which Pöch projected the films or the context in which they were shown, an analysis can only be tentative. However, the surviving films do invite questions about the influence of contemporary film aesthetics on early anthropological filmmaking.

In his initial report on his work in the POW camps, Pöch remarks that his possibilities were limited from the outset. ${ }^{42}$ The artificial setting and the lack of traditional costumes, he claimed, made "real" ethnographic film impossible. In contrast to his overseas expeditions, where, as Andrea Gschwendtner points out, Rudolf Pöch claimed not to intervene in the profilmic event in the camps he felt that anthropological "authenticity" had to be carefully staged. ${ }^{43}$

Österreichisches Bundesinstitut für den wissenschaftlichen Film 1991. See the supplementary information to the film in Gschwendtner, "Als Anthropologe im Kriegsgefangenenlager," 105-118.

42 Pöch, "1. Bericht," 230.

43 Gschwendtner, "Als Anthropologe im Kriegsgefangenenlager," 116. 
The compilation does not presume to follow any original order in which the films were spliced for presentation. However, the two groups correspond to the aesthetic conventions of the "attraction" and the "view." ${ }^{4}$ The first group focuses on kinetic events, like dances, leisure, and entertainment, corresponding to Gunning's notion of the "cinema of attractions." The panorama shot (2) over the crowd of prisoners has no anthropological value other than to emphasise that wedding dances are visual spectacles-for guests as well as the camera. The prisoners are obviously performing for the camera, acknowledging its presence either by looking directly at the lens or communicating with the operator or his assistants. The staged character of their performances receives additional emphasis from the visible presence of the camp: In almost all the outdoor scenes in the first group, except the "group dance," fences and guards are clearly visible. They form the rear edge of the "stage" and become part of the performance by continually marching in and out of the frame. The similar number of "attractions" and "views" raises the question of how the films were screened: Were the two genres projected alternately or in sequence, as in the compilation?

A close look at (3) and (6) shows that Pöch had a cast. Not only is the location the same, but also the actors. Pöch apparently chose his performers according to their skill with the camera. His reports describe how scenes were staged and rehearsed. ${ }^{45}$ The same goes for (4) and (5), but with a striking change of backdrop: The cast appears to be the same, but (4) is shot in front of the camp fence, while the next dance takes place in front of a shack. Why did Pöch change the scenery? Did he worry that a backdrop of fences and guards might distract viewers from the performance or detract from the film's anthropological quality?

In contrast to the theatricality of the first group, the craft scenes of the second group of films reflect Gunning's aesthetic of the view. However, in contrast to a travelogue that explores various aspects of a city, region, or country, viewers here do not explore space. Instead, the film's "dominant organization principle is temporal, detailing the stages of a process in a logical order." ${ }^{\prime 66}$ The overall principle of (9), (11), and (15) is the two-shot film in which the second shot either offers the viewer a better perspective on the manufactured item as in (11) or shows a further stage in production as with (9) and (15).

44 In his reports, Pöch does not mention the exhibition context of his films. Unfortunately, it was impossible to have access to Pöch's personal files and records due to an ongoing research project on Pöch by the Austrian Research Foundation titled "Rudolf Pöch-Anthropologe, Forschungsreisender, Medienpionier," FWF-Forschungsprojekt P17761-G6, 2005. See also http://poech.fox.co.at (accessed May 21, 2010).

Gunning, "Before Documentary," 17. 
The most striking sequence in the film is certainly the plaster casting of a prisoner's head, the final scene in the compilation. It is composed of two shots. The first outdoor shot shows two scientists, masked with white hoods, applying plaster to a prisoner's head. Straws in his nostrils prevent asphyxiation. Another prisoner assists by mixing plaster in a bowl. The second shot shows final steps in reproduction. Two men, presumably the same as in the previous shot, display their skill in turning the plaster mold into a replica of the prisoner's head. In contrast to the previous shot, the scholars are now casually dressed with turned-up sleeves and caps more reminiscent of Bohemian sculptors than academics. The staging of the second shot recalls a magic trick or a presentation of the latest technical wonder. Vaudeville acts were often included in early film programs that combined entertainment with science and education.

What makes the sequence unsettling is not only the scientists' white hoods, but their callous treatment of the prisoner. The "original" is obviously of less value to them than the reproduction. While the filmic documentation of anthropological method stands in remarkable juxtaposition to the documentation of the craft techniques of the prisoners, the didactic purpose of the concluding film comments on anthropology's aim to "record for posterity" in its own particular way.

Pöch was not a commercial film operator by trade. However, a handbook of ethnographic filmmaking that he wrote in the 1910s shows that he was familiar with early film aesthetics. ${ }^{47}$ His technical recommendations incorporate an aesthetic dimension. He recommends that anthropological filmmakers, beyond thinking about how to shoot wirksame [effective or striking] images, take time to study successful programming in local cinemas. Models available there followed Gunning's "view" aesthetic: tinted or hand-colored nonfiction films, with the formulaic structure of the travelogue. Pöch's recommendations suggest that popular commercial films serve as models for scientific work. He seems to have been interested in reaching a broader audience. This interest is evidenced by his allowing his anthropological photographs and casts of prisoner's heads to be displayed at the Viennese War Exhibitions of 1916 and $1917^{48}$

Pöch seems to have quit filming in the camps by September 1915. We do not know his reasons. It is possible that the footage obtained was already suf-

47 I would like to thank Dr. Susanne Ziegler from the Phonogram Archive at the Museum of Ethnology in Berlin for drawing my attention to this document, which could be identified as having been written by Pöch. Untitled File, Berliner Phonogramm-Archiv, Staatliche Museen zu Berlin-Preußischer Kulturbesitz, Ethnologisches Museum. berichte, 36-37. 
ficient for his aims. Perhaps he was dissatisfied with the need for intervention in film shots that made them appear less authentic to him. This perception seems to be behind his statements to the effect that staged events could never substitute for fieldwork on site. Moreover, a comparison of his films with the travelogues he appears to have imitated shows that aesthetic considerations moved his films toward the realm of popular "attractions" and "views." This may have been a deeper source of his dissatisfaction with filming in the camps. After September, 1915, Pöch concentrated almost exclusively on physical anthropology, which would remain his specialty as well as that of his students.

Pöch may have realized that images from POW camps inevitably entail a kind of voyeurism that anthropological filmmaking simultaneously feared and had never been without. His motives to stop filming in the camps-whatever they may have been-seem to point to an epistemological problem for the genre as a whole. He and his films both suffered under their limited scientific value. As evidenced in his films' apparent similarity to the commercial offering Südwest-Afrika, what distinguishes Pöch's films from popular cinema cannot be located in the images themselves, but only in the scientific context. Stripped of their scientific aura, his films exploit the same Schaulust and unleash the same pleasures, powers, and dangers of looking.

Pöch's POW-camp films mark the end of ethnographic film's initial phase. Even before he began work, discussion of the value of film for ethnography was in full swing. The medium was rapidly losing its credibility as a purely documentary technology, as the private correspondence between two German ethnographic filmmakers shows: In letters dating from 1914, Theodor KochGrünberg and Fritz Krause agree that ethnographic film can only illustrate the spoken word. ${ }^{49}$ Only with forceful contextualization by the lecturerthe ethnographer-could ethnographic film images produce ethnographic meaning. ${ }^{50}$

A turn to the narrative aesthetic that came to dominate popular entertainment solved ethnographers' dilemma of producing films that did not require accompanying lectures which guided the viewers' attention and understanding. "Attractions" and "views" did not disappear, but they became integrated into producer-driven narratives, establishing a new rhetoric in nonfiction film-the documentary.

49 VKMr A 14. Nachlass Theodor Koch-Grünberg at the Institut für Vergleichende Kulturforschung, Phillips-Universität Marburg.

50 Ibid. 
